\title{
THE ROLE OF PRAGMATIC FUNCTION IN THE GRAMMATICALIZATION OF ENGLISH GENERAL EXTENDERS
}

\author{
Maryann Overstreet
}

\begin{abstract}
In a number of recent studies, developments in the structure of English general extenders (e.g. and stuff (like that), or something (like that)) have been investigated from the perspective of grammaticalization. These developments have mostly been described in terms of formal changes as a result of processes identified as morphosyntactic reanalysis, phonological attrition and decategorialization. In this study, I first describe the impact of these changes on the structure of general extenders, confirming the usefulness of the basic grammaticalization framework as a way of accounting for developments in linguistic expressions (such as discourse markers or pragmatic markers) that are not considered to be grammatical markers in the traditional sense. I then use a more recent version of the grammaticalization framework to investigate the extent to which general extenders have developed meanings that can be described as subjective (speaker-oriented) and intersubjective (addressee-oriented). In this development, general extenders have come to be used as hedges on expectations of informativeness and accuracy, primarily involving subjective meanings, and as indicators of positive and negative politeness strategies, which carry intersubjective meanings. In this analysis, pragmatic functions are shown to have a significant role in the linguistic changes associated with grammaticalization.
\end{abstract}

Keywords: General extenders; Grammaticalization; Intersubjectivity; Pragmatic function; Pragmatic markers; Subjectivity.

\section{Introduction}

A number of recent studies have pointed to processes associated with language change in the development of a group of linguistic expressions called general extenders (e.g. and stuff (like that), and things (like that), or something (like that)). Earlier observations by Aijmer (1985) Erman (1995) and Overstreet (1999) on changes in the form and function of general extenders have found support in several recent sociolinguistic studies by Cheshire (2007), Dennis (2011), Levey (2012), Pichler \& Levey (2011) and Tagliamonte \& Denis (2010). The primary focus of the sociolinguistic studies has been on variation in the formal instantiation and distribution of general extenders, for example, noting the decreasing use of and things alongside the increasing prevalence of and stuff in North American varieties and among some middle class speakers of British English, while and (all)that is the more common form heard in British varieties, 
particularly among male working class speakers (Cheshire 2007; Tagliamonte \& Denis 2010). These studies have included reports of a number of structural changes in the way general extenders are being formed and used, employing concepts developed in the analysis of grammaticalization (Traugott 1982; Hopper \& Traugott 2003). The changes have mostly been described in formal terms, involving reduction in form through morphosyntactic reanalysis, phonological attrition and decategorialization, similar to general mechanisms of change identified in previous studies of grammaticalization (Heine 2003; Hopper 1991).

The grammaticalization framework also provides a development pathway that can be used to identify the pragmatic functions that may have motivated the observed structural changes. As Hopper has pointed out, "changes result not from purely language-internal factors, but from verbal interactions among speakers" (2010: 181), so it is possible to look beyond the observed changes in linguistic form and consider which aspects of verbal interactions are involved in changes in the meaning or function of those forms. This pathway involves change from propositional meaning to expressive meaning, which is further divided into subjective (speaker-oriented) and intersubjective (addressee-oriented) meaning (Traugott 2003a, 2010).

In this paper, I will first describe some of the documented changes in the most common linguistic forms used as general extenders. I will then shift the focus from the analysis of the formal features of general extenders to their increased use with expressive meaning, developing pragmatic functions as hedges on expectations of informativeness and accuracy and as indicators of positive and negative politeness strategies. I will include examples from my own research on American English (Overstreet 1999, 2005, 2011), the British and Canadian sociolinguistic studies listed earlier, and other studies of general extenders covering different periods and varieties of English (Aijmer 1985, 2002, 2013; Carroll 2008; Channell 1994; Erman 1995; Evison, McCarthy \& O'Keeffe 2007; Fernandez \& Yuldashev 2011; Norrby \& Winter 2002; Palacios Martínez 2011; Stenström, Andersen \& Hasund 2002; Winter \& Norrby 2000; Youssef 1993).

\section{General extenders}

The term "general extenders" is now used as a category label for a wide range of expressions with similar positional and compositional features. In their most frequent realization, they are phrase- and clause-final, consist of and/or plus a vague nominal/proform, with an optional comparative phrase (like that). Those beginning with and are described as adjunctive general extenders and those beginning with or are disjunctive general extenders (Overstreet \& Yule 1997a: 87). These forms are typically optional and attach to otherwise grammatically complete utterances. They are mostly found in spoken English, particularly among younger speakers, and perhaps as a consequence are virtually absent from older descriptive grammars of the English language.

In Biber et al.'s (1999) corpus-based grammar of spoken and written English, several of these expressions are included in a category that is identified as part of the grammar of the English phrase. They are (in order of frequency) or something, and everything, and things (like that), and stuff (like that), which are described as "coordination tags" (Biber et al. 1999: 115-117). This label has not been widely 
adopted, but the linguistic category it describes has clearly become established as part of the English language. What are now described as general extenders had actually been recognized as examples of some type of linguistic category much earlier, having been noted by Ball \& Ariel (1978) and investigated more thoroughly by Dines (1980). A number of other analytic approaches, employing a range of different terms and looking at different varieties of English, have focused on these expressions in recent years, with the result that a very large number of forms have been identified as instantiations of the category. ${ }^{1}$

To take one recent example, in their study of spoken English in the town of Berwick-upon-Tweed (population about 13,000) in north-east England, Pichler \& Levey listed seventy-five distinct forms used as general extenders by "a socially homogeneous group of working-class speakers" (2011: 447). I will not be attempting to account for all uses of these forms, mainly because, as Pichler \& Levey (2011: 470) demonstrate, most of the forms, including or owt like that, are used only rarely in their substantial database, while a small number of forms are used a lot. I will focus on the small group of general extenders that occur frequently in data reported not only from north-east England, but from a range of other areas in the English-speaking world, as exemplified in $(1)-(6) .^{2}$

(1) I go out with my friends and stuff ... I'm not into big club things and stuff

(2) I quite like English food actually I love roasts and things like that

(3) Her dad's very well brought up. He went to Oxford and everything.

(4) she normally goes there and sits on the swings and that

(5) I might go over and teach languages or something in France or something

(6) We don't mean to cause a fuss or anything, but this isn't what we ordered.

From these examples we can see that, as shown in (7), based on Dines (1980: 28), the basic structure of an English general extender consists of a conjunction (and, or) and a vague proform, which can be a generic nominal (stuff, things) or a pronominal (that, everything, something, anything). The quantifier all is sometimes included with pronominal that. A modifier (like that) is used with some of these forms, distinguishing long forms (and stuff like that) from short forms (and stuff), a distinction that will be discussed later. ${ }^{3}$

${ }^{1}$ Among other descriptive labels used for those expressions identified here as general extenders are "set marking tags" (Dines 1980), "utterance-final tags" (Aijmer 1985), "generalized list completers" (Jefferson 1990), "vague category identifiers" (Channell 1994), "discourse extenders" (Norrby \& Winter 2002), and “vague category markers" (Evison, McCarthy \& O’Keeffe 2007).

2 The sources of these examples are (1) from Norrby \& Winter (2002), describing Australian English, (2) and (5) from Cheshire (2007), (3) from Palacios Martínez (2011), (4) from Levey (2012), all describing British English, and (6) from Overstreet \& Yule (2001), describing American English. Aijmer (2013) presents a comprehensive review of the frequency and distribution of general extenders in several varieties of English.

There have also been studies of general extenders in other languages, including Brazilian Portuguese (Roth-Gordon 2007), French (Dubois 1992; Secova 2011), German (Overstreet 2005; Terraschke 2007; Terraschke \& Holmes 2007), Japanese (Lauwereyns 2002), Lithuanian (Ruzaite 2010), Norwegian (Hasselgren 2002), Persian (Parvaresh et al. 2012), Spanish (Cortés Rodríguez 2006) and Swedish (Norrby \& Winter 2002; Winter \& Norrby 2000).

${ }^{3}$ Although it was infrequent and not socially diagnostic for her population, Dines (1980: 23) also 
(7)

$\begin{array}{cll}\text { conjunction } & \text { proform } & \begin{array}{l}\text { modifer } \\ \text { (like that) }\end{array} \\ \text { stuff } & \begin{array}{l}\text { (like that) } \\ \text { everything } \\ \text { (all) that } \\ \text { (like that) }\end{array} & \\ \text { or } & \begin{array}{l}\text { something } \\ \text { anything }\end{array} & \begin{array}{l}\text { (like that) } \\ \text { (like that) }\end{array}\end{array}$

As forms that are typically found in spoken interaction, general extenders would seem to have something in common with the larger range of words and phrases described as pragmatic operators (Östman 1981). In more recent analyses (Aijmer 2013; Aijmer \& Simon-Vandenbergen 2011; Brinton 2006, 2008), they are described as pragmatic markers with a role in interactive spoken discourse that is comparable to expressions such as I mean, you know, well, in fact and actually. The latter forms are often treated as examples of discourse markers, along with but, oh, okay, now, right and so, fulfilling roles in the structural organization of text and interaction (Fraser 1999, 2010; Jucker \& Ziv 1998; Schiffrin 1987).

However, there are some notable differences between the typical uses of discourse markers and general extenders. Discourse markers function parenthetically and, while some can occur in different positions within utterances, they are primarily "left-hand" markers in English (Watts 1989: 211). As Schourup has noted, "discourse markers frequently cluster at utterance onset" (1999: 233) where they usually signal a sequential discourse relationship. In a more recent study, they are defined as "expressions whose prime function is to mark relations between sequentially dependant units of discourse, and which specify the way in which what follows is connected to what has taken place before" (Prévost 2011: 393-4). Discourse markers are a "heterogeneous syntactic group" (Fraser 2010: 126) and are "independent of syntactic structure" (Schiffrin 1987: 32).

In contrast, general extenders have a fairly homogeneous structural template, as shown in (7), and are almost exclusively "right-hand" markers used in a fixed position, immediately following the phrases, clauses and utterances with which they occur. The fixed position of general extenders might better be described as a "post-position" relative to the rest of a phrase or clause, providing speakers with the option of adding modifications and an opportunity to influence the interpretation of what is being said. English general extenders tend to be put at the end of utterances and indeed this structural feature is found in many definitions of the forms as "utterance-final" (Aijmer 1985: 366) or even "sentence-final" (Tagliamonte 2011: 258). ${ }^{4}$

noted another type of adjunctive general extender construction with the following basic linear template: [and $][($ all $)][$ that / this] [kind / sort / type $][$ f $]$ [stuff / thing]. Perhaps due to its infrequency, this construction has received little attention in studies on general extenders.

\footnotetext{
${ }^{4}$ The common occurrence of general extenders in clause-final position may be a typological effect of English SVO clause structure, which puts objects (with general extenders) at the end. In a language with SOV clause structure, such as Persian, objects (with general extenders) routinely occur in a midclause position, as in homin $d z$ âke in mae'âfi va inâ râ midaen ('the place in which they give exemption from military service and stuff'), a feature exemplified and discussed in Parvaresh et al. (2012: 268-70).
} 
While this position is typical, it is not the only one possible. Though not common in research reports, evidence of English general extenders being attached to subjects can be found for forms that are disjunctive, as in (8) from Overstreet (1999: 54) and (9) from Aijmer (2002: 245), and adjunctive, such as (10) from Stenström, Andersen \& Hasund (2002: 102). A particularly interesting case from the speech of a young girl (aged ten) in London, noted by Levey (2007), is presented in (11).

(8) I thought some poison in his drink or something like that a few weeks down the road would kill him

(9) I got my coat and everything caught under me and a young postman or something got up and I thought ooh this is grand

(10) Where did Chantal and that go?

(11) well normally like boys think that football's a boy game 'cause like David Beckham and all that are boys

It is rare to find a general extender that, if removed, would have an impact on the grammaticality status of the structure to which it is (normally optionally) attached. In the case of (11), however, removing and all that would result in the ungrammatical *David Beckham are boys. In this example, the general extender is being used in a role normally associated with an affix, which in this case seems to signal "group membership" with the referent of the

attached nominal rather than plural number of that nominal, an analysis that would also seem appropriate for example (10). Utterances such as (10) and (11) reveal a structural role (attached to subject) that has not previously been investigated in studies of English general extenders and may provide some evidence that younger speakers are extending the uses of these forms. ${ }^{5}$

\section{Grammaticalization}

In the standard view, based on ideas in Meillet (1912 [1958]) and elaborated in Traugott (1982) and Hopper \& Traugott (2003), grammaticalization is defined as "the change whereby lexical items and constructions come in certain linguistic contexts to serve grammatical functions, and once grammaticalized, continue to develop new grammatical functions" (Hopper \& Traugott 2003: 18). The focus on the historical development of grammatical markers in earlier studies has been expanded in recent years to include structural changes in other expressions, including forms that are variously described as discourse markers/particles and pragmatic markers/particles/operators (see contributions in Degand \& Simon-Vandenbergen 2011). In most of these studies, there are two dimensions to the discussion of patterns of change, one concerned with specific mechanisms that account for the consistently observed reduction in formal structure, and the other concerned with the shifts in function that accompany, and may indeed motivate, those changes in formal structure

\footnotetext{
${ }^{5}$ Although I use aspects of the standard grammaticalization framework in this study, I am not trying to suggest that general extenders have become grammatical markers in Present-Day English. It is possible to find examples such as (11) where the use (or not) of a general extender with a subject can have an impact on the appropriate form of the verb in an utterance (which might suggest a grammatical role), but general extenders appear to be used more typically as pragmatic markers (Aijmer 2013).
} 
(Bybee 2003; Hopper 1991; Traugott 2003a, b; Traugott \& Heine 1991). In the following sections, I will describe and illustrate three well-established formal mechanisms of change as they relate to general extenders, which will then lead to an analysis of the ways in which these forms have developed new functions in Present-Day English.

The general finding, in the study of diachronic change, is that linguistic items move from a fully explicit form $(g o+i n g+t o)$, with lexical status (motion verb plus preposition), to a more grammatical form, such as /gonna/, that is used as a single and typically reduced form. What is important to remember is that the development of a linguistic item along this pathway in the direction of a more grammaticalized form (I'm not gonna do it), marking future temporal reference, does not necessarily obliterate its earlier status as a fully lexical form (I'm not going to London) while creating a coded grammatical distinction (*I'm not gonna London). The phenomenon of variants associated with two or more different functions is known as "layering" (Hopper 1991), "where a full form and a reduced form coexist" (Hopper \& Traugott 2003: 124). The existence of layering provides us with the opportunity to look at synchronic data for evidence that a particular type of variation in form may be associated with variation in function that has occurred over time. Having established the basic pattern of change noted in grammaticalization studies, I will now look at ways in which general extenders have undergone quite specific types of change via morphosyntactic reanalysis, phonological attrition and decategorialization.

\subsection{Morphosyntactic reanalysis}

Many of the general extenders that are commonly used in contemporary English have two related forms, one unmodified (or something, and things) and the other with a modifier (or something like that, and things like that). They are sometimes counted together as examples of a single form (e.g. Evison, McCarthy \& O'Keeffe 2007), but there is a clear structural difference in the way these forms are articulated and the use of a short form rather than a longer form may be socially significant, as noted in a recent study involving young (preadolescent) speakers of London English, where short forms were frequent and longer versions were almost absent from the data (Levey 2012: 274). The general pattern is that shorter forms are becoming more frequent and are no longer treated as a complex phrase consisting of several component elements, with the result that forms "that were formerly separate become stored and processed as a prefabricated phrase" (Cheshire 2007: 166).

In Present-Day English, the short form or something is the most frequent general extender in most surveys (e.g. Biber et al. 1999: 115-116) and has been used as a fixed phrase for some time. It is no longer viewed as having the components [or + some + thing], as Erman (1995) has noted, and is so idiomatic that its articulation is also typically reduced. That is, the separate morphosyntactic components of the original phrase have combined into a single form. This development is sometimes described as "fusion" (Hopper \& Traugott 2003: 44) or "automatization" (Bybee 2003: 603), both of which involve the reanalysis of a frequently used sequence of separate units as a single processing chunk. The long form (or something like that) continues to be a more explicitly cohesive expression (Aijmer 2002: 224), typically with a discernible antecedent for the anaphoric that (Cheshire 2007: 178). A similar distinction can be 
observed in the use of and stuff like that compared to 'nstuff (Overstreet 2011: 301). As may have become clear, the short forms of general extenders not only lose their cohesive link, they also lose some of their phonetic substance in a process described as phonological attrition.

\subsection{Phonological attrition}

One of the most consistent indicators that a linguistic expression is undergoing change or reanalysis is the general loss of phonological substance as it develops new functions (Lehman 1993), which is a common process in diachronic change tied to the fact that "expressions that undergo phonological reduction do so because they are frequent" (Boye \& Harder 2012: 29), a phenomenon explored in detail in Bybee (2003). When we look at general extenders, we find two aspects of phonological change, one at the suprasegmental level and the other involving the loss of phonetic segments, more generally known as phonological attrition.

Long forms of general extenders are more likely to occur as separate constituents in a distinct tone unit, whereas short forms are more often found inside a tone unit with other constituents. Occasionally speakers will use the long form without the conjunction (and/or), but preceded by a pause, clearly separating the general extender from the utterance before it. ${ }^{6}$ In the Hong Kong English corpus examined by Warren, the shorter form or something "was almost always spoken in the same tone unit as the item that it is tagged with" (2007: 187), while longer forms typically occurred in a separate tone unit. In Aijmer's (1985: 370-71) analysis of British English data, the short forms and things and or something were overwhelmingly used inside a tone unit, whereas their longer counterparts with the comparative phrase like that were much more likely to be in a separate tone unit by themselves. In addition, short forms were used much more frequently. This aspect of general extender use suggests that the short forms have become more integrated into the rhythmic structure of utterances, making them less salient in phonological terms.

When we look more closely at the pronunciation of some general extenders, we find a process at work that is leading to a reduction or loss of phonetic segments. In Cheshire's (2007) study of general extenders used by teenagers in three English towns, two of the most frequent forms that are listed are and that and or something. However, as Cheshire notes, "the unstressed and is reduced to $/ \mathrm{n} /$ in every case and or in or something is almost always pronounced as a schwa" (2007: 168). In both these forms, it is the conjunction that undergoes phonetic reduction, potentially reducing its role as a marker signaling any kind of overt cohesive link, and contributing to the impression that these short general extenders have undergone reanalysis as single forms. In their presentation of speech samples illustrating the uses of general extenders, researchers

\footnotetext{
${ }^{6}$ Winter \& Norrby (2000: 4) provide a good illustration of this difference in the following extract from their Australian English data.

When I've finished school I go home ... Walk home .. Um ... Get changed .. usually do my homework first . play some computer games and stuff ... things like that

In this case, the speaker uses a short general extender (and stuff) attached to a phrase, followed by a distinct pause, then a long general extender without a conjunction (things like that) attached to the whole utterance, closing off the turn.
} 
rarely include narrow phonetic transcriptions, but they often indicate that some forms are heard as reduced, even when reduction in form is not the focus of their analyses. The reduction of sounds and the omission of segments in the following extracts provide some support for the idea that or something is widely used in a reduced form, in British English (12) from Erman (1995: 144), Australian English (13), from Winter \& Norrby (2000: 6), and American English (14), from Guthrie (1994: 85).

(12) you get it out of the computer every six months o'someth'n

(13) or maybe an optometrist or some'ing

(14) there was like eight ta ten of 'em er somethin'

When we look at the adjunctive general extenders, we can also find examples in transcriptions where reduced forms are recorded. In Levey's (2012) study of preadolescent (London) speech, the form and everything was often articulated in the reduced form /oneveIn/. A fairly well-known older example is presented in (15), from the poem "A Man's a Man for a' that" by Robert Burns (1795 [1859]), providing evidence that, at least in eighteenth century Scotland, the general extender and all that was already being used in a reduced form. In (16), from an overheard conversation, jotted down in passing, the distinctly British form and that was regularly pronounced as /ənæ/, and in (17), from Guthrie's (1994) California data, the form and stuff was also heard in a reduced form.

(15) What though on hamely fare we dine, Wear hoddin grey, an' a' that

(16) we were having a party 'nat before leaving

(17) when I was married to Jim an' there was a sugar shortage an' a-like he sold pot 'nstuff

In the everyday talk of some American English speakers, as described by Aijmer (2013: 142) and Overstreet (1999: 103), the use of and stuff has not only become reduced in form ('nstu), it no longer has to attach to an antecedent noun phrase. In one documented case, Overstreet (1999: 103-4) identified an individual speaker (in a nurse to nurse conversation) who used the expressions y'know and 'nstuff (in either order) in a way that was so reduced in form and content that they seemed to be functioning as the oral equivalent of punctuation marks. Macaulay identified a similar phenomenon as "a kind of punctuation feature" (1985: 115) in one speaker's frequent use of and that. Expressions used in this way are now more generally described as "punctors" (Cheshire 2007; Vincent \& Sankoff 1992), as illustrated in (18).

(18) S: What about the organs

$\mathrm{K}$ : Yeah right see I was real concerned we're gonna have a problem

S: grow, yeah

$\mathrm{K}$ : But y'know 'nstuff as he got a little bit older 'nstuff y'know doctor told me and Justin was fine and has no problem but as he's gotten older you can see he's he's flattening out y'know' 'nstuff

This use of the reduced form of the general extender may simply serve as a means of keeping the conversation going, having a role in the prosodic structure of the utterance, but with no role at all in the information content, a function consistent with its phonologically reduced form. 


\subsection{Decategorialization}

At the same time that general extenders are undergoing changes in phonological form, they are also undergoing another type of reduction through a process described as decategorialization. In the traditional framework of historical linguistics, decategorialization is associated with the loss of morphosyntactic characteristics in a form as it develops new grammatical functions (Heine 2003: 579). In the study of general extenders, this process is identified with the mismatch that develops between the proform and the phrase to which it is attached in terms of both syntactic and semantic properties. In some of their uses, general extenders may exhibit a close grammatical connection between what is described as a "host" nominal and the proform included in the general extender. As illustrated in (19), from Fernandez \& Yuldashev (2011: 2611), the noun phrase an orange juice, acting as host, and the proform something share the grammatical features [non-animate] and [singular + count].

(19) Can you bring me an orange juice or something?

However, this type of strict grammatical relationship has eroded substantially, according to a number of studies, with the result that or something can also connect with nominal hosts that are [animate + plural], as in example (20) from Erman (1995: 143), [human] (21), and [human + plural] (22), as in two other examples from Fernandez \& Yuldashev (2011: 2612).

(20) there were a number of characters who I think were waiting to sell some sheep or cattle or something

(21) they think I'm a genius or something

(22) where people were so used to ... I don't know ... idiots or slackers or something

Further erosion of features indicating a close grammatical relationship is evidenced in the use of or something with forms other than a nominal host, such as an adjective (23), a verb phrase (24), as in these examples from Erman (1995: 141), or both a verb phrase and a preposition phrase in the same utterance, illustrated in (25) from Cheshire (2007: $170)^{7}$

(23) they saw him do it, probably was tight or something

(24) and he was perhaps sacked for something else, but I don't know, or made redundant or something

(25) I might go over and teach languages or something in France or something

These decategorialization effects can also be observed in the use of adjunctive general extenders. In a strictly referential use, we would expect the expression and things to be coordinated with non-animate plural count nouns as hosts, the form and stuff to be used with non-animate, non-count (or mass), singular (or indefinite plural) nouns, and the pronoun in and that to go with singular nouns. However, there is increasing evidence that adjunctive general extenders are no longer used in accordance

${ }^{7}$ As one reviewer pointed out, in some of these cases, particularly examples (21) and (23), the general extenders are attached to attributive forms (a nominal and an adjective) that identify a role or property rather than a person, illustrating their extended range of possible host forms. 
with these types of constraints, as exemplified in (26) - (30).

(26) they take disabled children and things around

(27) I wasn't expected to be sort of judged and criticized and things

(28) it's not the end of the world and stuff

(29) I go out with my friends and stuff ... I'm not into big club things and stuff

(30) she normally goes there and sits on swings and that

In (26), from Cheshire (2007: 169), and things is tied to a host (children) that is human and in (27), from Evison, McCarthy \& O'Keeffe (2007: 144), and things is not even connected to a preceding noun phrase, but is conjoined with verb phrases. In (28), from Palacios Martínez (2011: 2462), and stuff is connected to a singular count noun and in (29) from Norrby \& Winter (2002), and stuff is used after a noun that is plural count (things) and a verb phrase (go out with my friends). In (30), from Levey (2012: 258), the expression and that is connected to either a plural noun (swings) or a verb phrase (sits on swings), exhibiting the kind of referential ambiguity that can result from loss of a distinct grammatical connection.

In this analysis of the types of changes documented in the grammaticalization of general extenders, researchers have generally assumed that frequency of usage and associated ease of articulation are the major forces involved in the reduction in formal structure and other changes. Corpus-based studies of British English do reveal a substantial increase in the frequency of certain general extenders between the 1960s and the 1990s (Denis 2011: 63; Palacios Martínez 2011: 2461). But why should there be an increase in frequency? The phenomenon is at least partially explained by an increased range of functions served by these forms.

\section{From propositional/referential to expressive}

In their grammaticalization framework, using categories from Halliday \& Hasan's (1976) functional-semantic model, Hopper \& Traugott (2003) describe a typical pathway of development as linguistic expressions go through functional changes over time from having a propositional or ideational type of function to an expressive or interpersonal function. The propositional component is associated with truth-conditional relations and the use of forms with referential meaning, connecting language externally to a world of reference. The expressive component is concerned with the use of forms that are subject to interpretation in terms of a speaker's attitude and "the resources a language has for expressing personal attitudes to what is being talked about, to the text itself, and to others in the speech situation" (Traugott 1982: 248). Within this analytic framework, there is also a textual component, described in terms of "the resources available for creating a cohesive discourse" (1982: 248), which may involve the use of some general extenders. ${ }^{8}$ The major focus here, as in the earlier grammaticalization

8 "Textual" uses of general extenders will not be the focus of this paper. Research on how general extenders function at the textual level has been minimal. Winter \& Norrby reported on a high percentage being used at points "signalling turn exchange" (2000: 6) in their Australian data. A small group of forms do seem to be specialized at this level, however. As was recognized some time ago (Jefferson 1990; Lerner 1994), adjunctive general extenders can be used to suggest additional items in a list, thereby completing it textually, and certain forms are particularly associated with list-completion (Carroll 2007). One of the earliest recorded examples of a general extender type of expression in English is the form ant 
studies, is on how linguistic expressions with referential function, which is viewed as objective, come to be used with expressive function, which is inherently subjective.

According to the Oxford English Dictionary Online, there were distinct meanings for the noun stuff in the fifteenth century, such as "moveable property" in (31) and "materials for war" in (32). In contemporary English, stuff continues to be used, typically as a means of vague reference to material, as in (33) from Brautigan (1967: 83).

(31) All his other godes and stuffes meveable that he leveth vnto hem

(32) with a grete power ordenance and stuff

(33) One spring day she had me ascend to the attic and clean up some boxes of stuff and throw out some stuff and put some stuff back into its imaginary place.

When we look at the use of constructions containing and stuff as a general extender in Present-Day English, we can find some examples that seem to be tied to the original referential meaning, but many more uses where no reference to an actual mass of any kind is made and the form has more of an expressive function in the interaction. This pattern of functional change can also be discerned in the uses of other common general extenders such as and things and and everything.

Approaches to the analysis of general extenders that describe them as having a set marking or category marking function seem to be focused on their referential uses. In her pioneering study, Dines (1980) proposed that general extenders, or "set-marking tags" in her analysis, "serve a very definite function [...] marking the preceding element as a member of a set" and "in every case their function is to cue the listener to interpret the preceding element as an illustrative example of some more general case" (1980: 2223). This analytic approach captures those uses of adjunctive general extenders such as and stuff or and things like that where the speaker clearly has a verifiable set in mind and, in some particularly clear cases, will mention a superordinate set (e.g. evergreens, English food) within the same utterance, as in example (34), from Overstreet \& Yule (1997b: 253), and (35) from Cheshire (2007: 167). The basic referential meaning of these general extenders is that there are more examples or, considering the meaning of all adjunctive general extenders, simply that "there is more".

(34) Most of 'em are evergreens around there I guess - pine trees an' stuff (35) uh I quite like the English food actually I love roasts and things like that

In a similar vein, in their analysis of and everything as a variable with "various instantiations", Ward \& Birner propose that "in all cases felicitous use of and everything requires that such instantiations exist and constitute members of a well-defined (and in

so vorth from around 1325 (Carroll 2008: 13), which includes a form (vorth), with an earlier meaning involving physical motion, that had already developed into an abstract marker of continuation in Middle English. Its modern equivalent and so forth, together with the more frequent and so on, and their combination (and so on and so forth), as well as etcetera, can often be found at the end of lists. These forms are strongly favored in formal spoken discourse (Overstreet \& Yule 1997b: 252-3), and particularly in academic speech (Biber et al. 1999: 116; Simpson 2004: 48-50). These forms appear to have become specialized in their textual function and, while indicating that "there is more," they also signal "but this segment of text is complete," as in this example from Biber et al. (1999: 117): It includes information about the file such as its size, history, and so on. 
principle enumerable) set" (1993: 209). We will return to the analysis of and everything to illustrate some uses that would seem to have developed more of an expressive function, but it is clear that in some of these earlier approaches to the analysis of general extenders, it was the referential function that was emphasized. When Channell (1994) analyzed general extenders as examples of vague language, she also focused primarily on their referential meaning, proposing that a structure consisting of an exemplar plus a tag (bread or something) functions as a "vague category identifier" which "directs the hearer to access a set, of which the given item is a member whose characteristics will enable the hearer to identify the set" (1994: 122). In this case, the set was described as "anything edible." In this type of analysis, the general extender is clearly considered to be making a contribution to propositional meaning and researchers have often focused on this function as the major contribution that general extenders make to the utterance, particularly when using the description "set marking tags" (e.g. Ediger 1995; Stenström, Andersen \& Hasund 2002; Stubbe and Holmes 1995).

\subsection{From and Things to an ting}

The approach that focuses on category or set marking emphasizes cognitive processing in the interpretation of the referential range of general extenders and assumes that conversational participants have access to specific pre-existing sets and categories in some straightforward way. In an earlier use, cited by Tagliamonte \& Denis (2010: 364) from the Corpus of English Dialogues 1560-1760 (Kytö \& Culpeper 2006), there would seem to be a set marking use of and Things, as in (36) from the year 1739.

(36) she came in a Hackney-Coach with some Boxes and Things with her

In this example, Things has the capital letter used with nouns at the time and is connected to another plural noun, suggesting that there was in fact a set of objects involved. It is examples of this type that are often presented in support of the set marking approach. In many cases, typically when limited to a strictly linguistic point of view, this analytic approach may seem quite straightforward, with an expression such as forks and things being processed in a way that suggests an established superordinate category with a direct semantic relationship, more specifically identifiable as cutlery (Overstreet 1999: 47).

On another occasion, however, this process may not lead to such a straightforward identification of a category. Standing in line at a fast-food restaurant, you might hear a woman tell her son, Go get forks and things, then watch him return from a side counter with plastic forks, paper napkins, straws, and small packets of mustard and ketchup. In this case, and things did not suggest a specific set or category of objects, but a locally restricted group of items belonging to a non-lexicalized or ad hoc category, referencing not a set, but a loose collection of 'items you can get from a side counter to use with items ordered in a fast-food restaurant' (see Barsalou 1983; Overstreet \& Yule 1997a). We might look at this difference in the use of the expression forks and things as evidence of layering and the ability of general extenders to vary between marking a more objective referential connection, based on a fixed semantic relationship such as hyponymy, and indicating a more personal or expressive connection involving ad hoc categorizing based on different kinds of shared experience and 
knowledge, as illustrated by Evison, McCarthy \& O'Keeffe (2007) and O'Keeffe (2004). The general extender and things thus seems to be able to function as a marker of both referential and expressive meaning.

In the particular case of and things, we have noted some changes via decategorialization that suggest that this form has lost some of its earlier referential meaning. In fact, we already have evidence that, for one linguistic community, the superstrate English expression and things has developed a revised form (an ting) and a function that is predominantly interpersonal. In Youssef's study of Trinidad Creole, the form an ting is described as having "a double representation of solidarity, first as a Creole marker and second as a discourse feature entailing implicit shared knowledge" (1993: 291), as illustrated in examples like (37).

(37) But in case you pick up somebody an ting and intend having a sexual relationship you know

What Youssef (1993) illustrates very clearly is that "implicit shared knowledge" is the basis of most uses of this form. We will look more closely later at the processes involved in the type of revised form and function (i.e. marking a social connection) illustrated here by an ting, in contrast to the and Things example earlier in (36).

\subsection{The forms and everything, or anything}

Another illustration of a general extender with an earlier set marking function that has developed a clearly expressive meaning can be found in the use of and everything, not primarily to indicate "other members of a well-defined set" (Ward \& Birner 1993: 209), but to indicate that there is something remarkable or special in what is being said. In Aijmer's analysis, within a context where women don't normally wear veils, the speaker of (38) can use and everything to highlight information with the feature " $[+$ Remarkable]" (1985: 383). A similar effect is present in (39) from data analyzed by Palacios Martínez (2011: 2466).

(38) but I mean the women - the women wear veils and everything don't they

(39) Her dad's kind of very well brought up. He went to Oxford and everything.

In this use, as both Aijmer (1985: 383) and Overstreet \& Yule (2002) have argued, the general extender is functioning like an intensifier, allowing the speaker to emphasize his or her sense of how noteworthy the accompanying information is. It is worth noting that this development has taken place in the use of the short form (and everything) but not the long form (and everything like that), as documented in Cheshire (2007: 187).

In negative environments, the general extender or anything, as in (40), can be used with a similar expressive meaning, indicating that the information, from the speaker's point of view, is "hard to believe" (Aijmer 1985: 384).

(40) so she quite put him off and now he never rings up or anything

At the same time that and everything and or anything are involved in the speaker's selfexpression, they also function within the interaction as implicit invitations to the addressee to have the same evaluation ('special' or 'remarkable') of the information 
provided. The speaker is appealing to the addressee's co-conception of that evaluation. These two forms can also be used within other constructions such as formulaic disclaimers, which function as part of interaction management to maintain the integrity of the participation framework in the context of problematic social action, as illustrated in (41) from Overstreet \&Yule (2001: 46).

\section{(41) we don't mean to cause a fuss or anything, but this isn't what we ordered}

In (41), the speaker is faced with articulating a problematic social action (a complaint) and appeals to the addressee not to view his/her behavior as negative in any way. In making that appeal, the speaker includes or anything, not to indicate other referential instantiations of the preceding noun phrase or clause, but other social actions that they would both recognize as problematic. This type of use assumes shared familiarity with the way in which different social actions are evaluated and clearly has an expressive or interpersonal function. We might say that the speaker is attempting to control the social evaluation of the self, what Goffman characterized as "impression management" (1959: 205), so that the utterance is directed, not only to the addressee's self-image, but the addressee's image of the (speaker's) self.

\section{From subjective to intersubjective}

In the analysis of how general extenders come to be used with expressive meaning in spoken interaction, more attention has to be paid to the influence of the addressee and the effect of recipient design on how utterances are constructed. Increased awareness of this effect has resulted in a revision of the earlier grammaticalization framework. The original framework was based on a monological model, describing speaker output only. In later versions, awareness of the need for a dialogic component results in the expansion of the framework to account for more addressee-oriented phenomena. In more recent studies (e.g. Traugott 2003a, 2007, 2010; Traugott \& Dasher 2002), following a distinction attributed to Benveniste (1958 [1971]), the expressive component is further analyzed into two distinct dimensions involving subjectivity ("understood as relationship to the speaker and the speaker's beliefs and attitudes") and intersubjectivity ("understood as relationship to the addressee and the addressee's face"), as described in Traugott (2010: 30). As Traugott emphasizes, the notion of intersubjectivity used in studies of grammaticalization is tied to "the locutionary agent's expression of his or her awareness of the addressee's attitudes and beliefs, most especially their 'face' or 'self-image"' (2010: 33). Others (e.g. Nuyts 2001) have used the term intersubjectivity with a different focus, in some cases making the concept of a "shared evaluation" apply to a group, "possibly (but not necessarily) including the hearer" (Nuyts 2012: 58). For Traugott (2010), the term seems to have an interpretation that focuses on the speaker-addressee relationship. Nuyts identifies a crucial aspect of the development process being described here when he notes that "intersubjectification is a process whereby a linguistic element [...] assumes a function in the realm of interaction management" (2012: 67), which includes its use as a politeness marker, a pragmatic function we will consider in more detail later.

Returning to Traugott's (2010) expanded analysis, we can note that the propositional component is viewed as essentially non-subjective and a path of 
development is presented as in (42), where '(inter)subjective' means that an expression "has a newly coded (inter)subjective meaning" (Traugott 2010: 35).

(42) non-/less subjective > subjective > intersubjective

Traugott (2010: 46-49) illustrates this pathway of change by detailing the history of the phrase a bit (of) in English from designating something concrete, as in the bytt of an Appel (nominalized from the verb bite) around 1400, through processes of increasing abstraction until it develops a subjective function which a speaker can use as a way of downtoning the information in the utterance, with the meaning "somewhat." This shift from concrete to abstract meaning allows speakers to make use of the form when expressing personal attitude as illustrated in you see, I've been a bit of a fool again (attested in 1871), where the speaker is described as attempting to save his/her own face. The latter use, where there is a potentially negative interpretation, can also be seen as a type of hedge because of an imposition involving the addressee being made in the context, and as such, representing concern with the addressee's face, which Traugott describes as "pragmatically intersubjectified" (2010: 49) in that particular context. In this development, a noun with physical reference and a lexical function comes to be used over time as part of a modifying phrase with no physical reference and a new pragmatic function.

The first part of this change involves the use of linguistic expressions with subjective or speaker-based functions. We have already seen, in the use of and everything in examples (38) and (39), that this general extender can serve to signal the speaker's evaluation ('remarkable' or 'special') of the information in the utterance. A similar evaluative effect has been documented in studies of degree expressions (Bolinger 1972; Ghesquière \& Van de Velde 2011), in the "hyperbolic expressiveness" of heaps of and loads of (Brems 2004: 263), as well as in the development of downtoners such as fairly and pretty (Nevalainen and Risanen 2002) and also probably, from something that is independently "provable" (i.e. true or false) to something that reflects the speaker's perspective on what is "likely" (Nuyts 2012: 59). In all these cases, the grammaticalization process has involved increased subjectivity, with newer uses of the forms carrying the speaker's evaluation of the information in the utterance. This general process has also been described in terms of "pragmatic strengthening" which occurs when "speakers draw on knowledge not only of linguistic structure, but also of information packaging and retrieval, and on conversational heuristics of the kind: 'Say no more than you must and mean more thereby" (Traugott 2003b: 631). The Gricean conversational heuristic that Traugott mentions here has also been identified as the basis of a pragmatic function now associated with adjunctive general extenders (Overstreet 1999: 126-133).

\subsection{Pragmatic function and adjunctive general extenders}

Among the most common general extenders, we can discern subjective uses that fulfill pragmatic functions associated with cooperative interaction, as described in Grice (1975). In the case of adjunctive general extenders, such as and stuff and and that, the basic meaning of "there is more" is sometimes given a hedging function tied to expectations of the Gricean Quantity maxim that contributions should not be "more 
informative than is required" (Grice 1975: 45). ${ }^{9}$ In example (43), from Norrby \& Winter's (2000: 6) analysis of a girl's description of herself, there is a limited amount of detail, with general extenders used (twice) to convey what is presented as an active social life. In (44), from Overstreet (1999: 75) the speaker uses two general extenders to signal that more information could be provided, such as fuller descriptions of the houses and their inhabitants (though the speaker isn't quite certain), with the result that enough is said "for the current purposes of the exchange" (Grice 1975: 45).

(43) um. no, not really. no, not that I can think of. I like t' I like dancing and stuff ... I like partying ... dance parties and stuff

(44) there were ... some very very good houses rather old-fashioned but quite good houses ... with very big rooms and that ... and these were sort of better class people ... people with maybe ... minor civil servants and things like that you know

In both these cases, the general extenders allow the speaker to limit what could be expressed more exhaustively and hedge on expectations of informativeness in interaction. The pragmatic function just described serves to indicate the speaker's concern with the amount of information in the utterance (i.e. being brief), which is a subjective concern (Traugott 2003b: 631).

However, "being brief" will vary in its implementation depending on the addressee, so an added function develops when speakers go on to use these forms to involve the addressee in the construction of the meaning of the utterance. When speakers use adjunctive general extenders to mark the limits of the informativeness of their message, they can also thereby indicate how much they assume can be treated as shared (unstated) information. Not only are the speakers of (43) and (44) using general extenders to limit the amount of what they think needs to be said, they are indicating that they and their addressees share the assumed information or can accept it as assumed. In some cases, speakers use adjunctive forms when they are confirming (or reminding the addressee of) shared knowledge, as in the use of and all that in (45) from Aijmer (2002: 235) and and that in (46) from Pichler \& Levey (2010: 18). ${ }^{10}$

\section{(45) I realize he's applied before sort of thing and all that}

(46) you know you're on about like sort of em Tweedmouth and Spittal and that

In both these uses, the speaker is directly appealing to information shared with the addressee. This points to another pragmatic function, often identified as a positive politeness strategy used to signal that speaker and addressee share common ground and

\footnotetext{
${ }^{9}$ The use of certain linguistic expressions as hedges is first described in Lakoff (1972) and examined in detail with reference to Gricean maxims in Brown \& Levinson (1987), the source of these two definitions: Quantity hedges "give notice that not as much or not as precise information is provided as might be expected" (1987: 166) and Quality hedges "suggest that the speaker is not taking full responsibility for the truth of the utterance" (1987: 164).

10 As Overstreet (1999: 12) and Pichler \& Levey (2010: 17) have noted, there is often a cooccurrence of general extenders with other discourse and pragmatic markers in spoken discourse. As exemplified in (45) and (46), the use of other forms such as like, sort of and you know reinforces the expressive meaning conveyed by the general extenders.
} 
have similar backgrounds, often in terms of social knowledge (Brown \& Levinson 1987). In this analysis, the general extenders are treated as forms that can be used to indicate familiarity and social connection. As a number of researchers have noted (Aijmer 2002; Evison, McCarthy \& O'Keeffe 2007; Palacios Martínez 2011; Overstreet \& Yule 1997b), adjunctive general extenders are now frequently used in English discourse to signal an assumption of shared experience and solidarity with the addressee, thereby marking attention to the addressee's self-image in terms of positive politeness. As a result, we can say that the most common adjunctive general extenders in English show evidence of having developed an intersubjective meaning, "in the sense of the development of meanings that encode speaker/writers' attention to the cognitive stances and social identities of addressees" (Traugott 2003a: 124).

\subsection{Pragmatic function and disjunctive general extenders}

In the case of expressions used as disjunctive general extenders, we can find examples from a much earlier period in the English language where a concern with the correct reporting of another's speech seems to be marked, as in the two expressions involving or something in (47) and (48) from the late seventeenth century, cited by Tagliamonte \& Denis (2010: 365) from The Corpus of English Dialogues (Kytö \& Culpepper 2006).

(47) he said he would not give it me, but If I brought any of our Masters, he would slit their Noses or something to that Effect

(48) she said, this Abby was formerly filled with Benedictine Monks, or something to that purpose

These examples indicate the speaker's concern that what is being reported may not be completely accurate. This usage allows us to trace a connection in terms of pragmatic function, similar to that detailed for the adjunctive forms, from a hedge on the information content of an utterance, tied to a pragmatic principle such as Grice's Quality maxim (Grice 1975: 46), essentially subjective in nature, to a marker of negative politeness, which is intersubjective in its concern with the addressee's face needs.

Disjunctive general extenders in English such as or something have a basic meaning of "there is an alternative", which we have already seen in (47) and (48) can indicate "I may be inaccurate", fulfilling one obvious pragmatic function, as further illustrated in (49) and (50) from Overstreet (1999: 114).

(49) I'm not sure exactly what happened either, but they ended up having these huge riots there. An' it was like for gay discrimination or something

(50) I think they must've broke up or something

In both these cases the speaker is indicating that there may be an alternative explanation for what is being reported or described while also showing an awareness of expectations tied to a pragmatic principle like Gricean Quality, where accuracy and/or not saying "that for which you lack adequate evidence" (Grice 1975: 46) is assumed. Although it is conceived within a speaker-addressee framework of cooperation, the Gricean Quality 
maxim is inherently speaker-based, specifying a relationship between the speaker and the accuracy of the report (i.e. what is said) and hence is fundamentally subjective in orientation and as such includes no concern with the addressee's self-image.

There are other uses, however, where or something has developed an additional pragmatic function. These uses are typically found when the speaker is producing an utterance that involves some form of potential imposition on the addressee, as in a request (51), an invitation (52) or a proposal (53).

(51) Could we, when you give us our essays back, and give us titles could we sort of meet or something?

(52) What are you doing tonight, you know, do you wanna go out or something?

(53) Julie: Come over an' hang out

Donna: kay

Julie: We can always, y'know, just yack an' have dinner

Donna: Okay

Julie: An' we could even go

Donna: But

Julie: for a walk or something if ya wanna go

In (51), from Channell (1994: 135), there is a tentativeness in the speaker's request (as a student addressing a teacher) that is indicated by a disjunctive form (or something) after the verb. There is also no real hint of an alternative event in the use of meet or something. Instead, the use of a form suggesting an alternative possibility represents an attempt to minimize the implicit imposition on the addressee and thus represents a strategy of negative politeness (Brown \& Levinson 1987: 65-66).

In (52), from Palacios Martínez (2011: 2453), there is a structure commonly used with or something in invitations. Since agreement with this invitation would involve the addressee's compliance, there is a potential imposition being articulated and a hedge (or something), nominally marking alternative possibilities (including 'or not'), is used to soften the impact of the imposition, again implementing a strategy of negative politeness. In (53), from Overstreet (1999: 105-6), the speaker (Julie) proposes different activities and includes or something as part of her attempt to make suggestions, but not impose them, as she incorporates one of the basic elements of negative politeness, expressed by Lakoff as "Give options" (1973: 298). Immediately after using or something in this utterance, Julie includes an additional hedge (if ya wanna go), reinforcing her strategy of negative politeness at this point in the interaction.

In all these examples, there is an attempt by the speaker to mitigate any threat to the addressee's face or self-image, marking the possibility of an alternative by using or something, in what Jucker \& Taavitsainen describe as "non-imposition politeness" (2013: 115). This general extender seems to have developed a distinctly intersubjective meaning and is now used and recognized with a pragmatic function relating to politeness in English discourse.

\section{Conclusion}

In this paper, I have offered evidence from recent studies of English general extenders 
to show that they exhibit the type of variation in form and function that would be consistent with a layering effect, as described in the analysis of grammaticalization. In this case, layering is connected to multifunctionality in the use and interpretation of certain common expressions. The layering effect also helps to explain how different developments in these linguistic expressions over time result in several versions of the expressions existing simultaneously, so that we find and stuff like that used alongside and stuff and ' $n s t u$, for example, with each form illustrating different levels of grammaticalization in terms of formal mechanisms of change described as morphological reanalysis, phonological attrition and decategorialization. After illustrating the results of each of these processes, I investigated how changes in the formal structure of general extenders could be related to changes in pragmatic function that would also be consistent with a proposed pathway of development in grammaticalization studies from non-subjective to subjective and intersubjective meanings.

My basic argument is that literal (non-subjective) referential meanings of general extenders can be identified in some uses where the existence of "more possibilities" (for adjunctive general extenders) or "other possibilities" (for disjunctive general extenders) is signaled. In other uses, the meaning of some general extenders can be analyzed as subjective when they are used as hedges on informativeness (adjunctive) and accuracy (disjunctive) in reporting/describing, reflecting a concern of the speaker that the utterance is appropriately constructed to carry his or her intended meaning. An additional function, relating to a concern with the addressee's self-image, is expressed in terms of two dimensions of politeness. Adjunctive general extenders become indicators of a positive politeness strategy, appealing to common ground, shared experience and hence social solidarity as the basis for interpreting what is being said. Disjunctive general extenders become indicators of negative politeness, appealing to other possibilities, in order to avoid the impression of an imposition on the addressee in what is being said. These latter meanings have become commonplace in the use of general extenders in Present-Day English as a result of new pragmatic functions having developed in spoken discourse.

\section{Acknowledgement}

I am indebted to George Yule for advice and examples, and to the editor and two anonymous reviewers for their many helpful comments on an earlier version of this paper.

\section{References}

Aijmer, Karin (1985) What happens at the end of our utterances? The use of utterance-final tags introduced by And and Or. In Ole Togeby (ed.), Papers from the Eighth Scandinavian Conference of 


\section{Maryann Overstreet}

Linguistics. Copenhagen: Copenhagen University, Institut für Philologie, pp. 366-389.

Aijmer, Karin (2002) English Discourse Particles. Amsterdam: John Benjamins Publishing Company.

Aijmer, Karin (2013) Understanding Pragmatic Markers Edinburgh: Edinburgh University Press.

Aijmer, Karin, and Anne-Marie Simon-Vandenbergen (2011) Pragmatic markers. In Jan Zienkowski, JanOla Östman, and Jef Verschueren (eds.), Discursive Pragmatics. Amsterdam: John Benjamins Publishing Company, pp. 223-243.

Ball, Catherine, and Mira Ariel (1978) “Or something, etc.”. Penn Review of Linguistics 3: 35-45.

Barsalou, Lawrence (1983) Ad hoc categories. Memory and Cognition 11: 211-227.

Benveniste, Émile, (1958 [1971]) Subjectivity in language. In Mary Elizabeth Meek (Trans.), Problems in General Linguistics. Coral Gables, Florida: University of Miami Press, pp. 223-230.

Biber, Douglas, Stig Johansson, Geoffrey Leech, Susan Conrad, and Edward Finegan (1999) Longman Grammar of Spoken and Written English. London: Longman.

Bolinger, Dwight (1972) Degree Words. The Hague: Mouton.

Boye, Kasper, and Peter Harder (2012) A usage-based theory of grammatical status and grammaticalization. Language 88: 1-44.

Brautigan, Richard (1967) Trout Fishing in America New York: Dell.

Brems, Lieselotte (2004) Measure noun constructions: Degrees of delexicalization and grammaticalization. In Karin Aijmer, and Bengt Altenberg (eds.), Advances in Corpus Linguistics. Amsterdam: Rodopi, pp. 249-265.

Brinton, Laurel (2006) Pathways in the development of pragmatic markers in English. In Ans van Kemenade, and Bettelou Los (eds.), The Handbook of the History of English. Oxford: Blackwell, pp. 306334.

Brinton, Laurel (2008) The Comment Clause in English. Cambridge: Cambridge University Press.

Brown, Penelope, and Stephen Levinson (1987) Politeness Cambridge: Cambridge University Press.

Burns, Robert (1795 [1859]) “A Man's a Man for a' that". The Complete Works of Robert Burns. Boston: Phillips, Sampson and Company, p. 302.

Bybee, Joan (2003) Mechanisms of change in grammaticalization: The role of frequency. In Brian Joseph, and Richard Janda (eds.), The Handbook of Historical Linguistics. Oxford: Blackwell, pp. 602-623.

Carroll, Ruth (2007) Lists in letters: NP-lists and general extenders in early English correspondence. In Isabel Moskowich-Spiegel, and Begoña Crespo-García (eds.), Bells Chiming from the Past. Amsterdam: Rodopi, pp. 37-53.

Carroll, Ruth (2008) Historical English phraseology and the extender tag. Selim 15: 7-37.

Channell, Joanna (1994) Vague Language. Oxford: Oxford University Press.

Cheshire, Jenny (2007) Discourse variation, grammaticalisation and stuff like that. Journal of Sociolinguistics 11: 155-193.

Cortés Rodríguez, Luis (2006) Los elementos de final de serie enumerativa del tipo 'y todo eso, o cosas así, y tal etc': Perspectiva interactiva. Boletín de Lingüística 18.26: 102-129. 
Denis, Derek (2011) Innovators and innovation: Tracking the innovators of and stuff in York English. University of Pennsylvania Working Papers in Linguistics 17: 61-70.

Degand, Liesbeth, and Anne-Marie Simon-Vandenbergen (eds.) (2011) Grammaticalization, pragmaticalization and/or (inter)subjectification: Methodological issues for the study of discourse markers. Thematic issue. Linguistics 49: 2.

Dines, Elizabeth (1980) Variation in discourse - 'and stuff like that.' Language in Society 1: 13-31.

Dubois, Sylvie (1992) Extension particles, etc. Language Variation and Change 4: 179-203.

Ediger, Anne (1995) An analysis of set-marking tags in the English language. Ph.D. Dissertation, University of California Los Angeles.

Erman, Britt (1995) Grammaticalization in progress: The case of or something. In Inger Moen, Hanne Simonsen, and Helga Lødrup (eds.), Papers from the XVth Scandinavian Conference of Linguistics. Oslo: University of Oslo, Department of Linguistics, pp. 136-147.

Evison, Jane, Michael McCarthy, and Anne O'Keeffe (2007) 'Looking out for love and all the rest of it': Vague category markers as shared social space. In Joan Cutting (ed.), Vague Language Explored. Basingstoke: Palgrave MacMillan pp. 182-197.

Fernandez, Julieta, and Aziz Yuldashev (2011) Variation in the use of general extenders and stuff in instant messaging interactions. Journal of Pragmatics 43: 2610-2626.

Fraser, Bruce (1999) What are discourse markers? Journal of Pragmatics 31: 931-952

Fraser, Bruce (2010) Discourse markers. In Louise Cummings (ed.), Encyclopedia of Pragmatics. London: Routledge, pp. 125-129.

Ghesquière, Lobke, and Freek Van de Velde (2011) A corpus-based account of the development of English such and Dutch zulk: Identification, intensification and (inter)subjectification. Cognitive Linguistics 22: 765-797.

Goffman, Erving (1959) The Presentation of Self in Everyday Life. New York: Doubleday.

Grice, H.P. (1975) Logic and conversation. In Peter Cole, and Jerry Morgan (eds.), Syntax and Semantics 3: Speech Acts. New York: Academic Press, pp. 41-58.

Guthrie, Anna (1994) Quotative tense shift in American English authority-encounter narratives. M.A. Thesis, California State University, San Bernadino, California.

Halliday, Michael, and Ruqaiya Hasan (1976) Cohesion in English. London: Longman.

Hasselgren, Angela (2002) Learner corpora and language testing. In Sylviane Granger, Joseph Hung, and Stephanie Petch-Tyson (eds.), Computer Learner Corpora, Second Language Acquisition and Foreign Language Teaching. Amsterdam: John Benjamins Publishing Company, pp. 143-173.

Heine, Bernd (2003) Grammaticalization. In Brian Joseph, and Richard Janda (eds.), Handbook of Historical Linguistics. Oxford: Blackwell, pp. 575-601.

Hopper, Paul (1991) On some principles of grammaticalization. In Elizabeth Traugott, and Bernd Heine (eds.), Approaches to Grammaticalization, vol. 1. Amsterdam: John Benjamins Publishing Company, pp. 17-36.

Hopper, Paul (2010) Grammaticalization. In Louise Cummings (ed.), Encyclopedia of Pragmatics. London: Routledge, pp. 180-182. 
Hopper, Paul, and Elizabeth Traugott (2003) Grammaticalization. (2 ${ }^{\text {nd }}$ edition) Cambridge: Cambridge University Press.

Jefferson, Gail (1990) List-construction as a task and resource In George Psathas (ed.), Interaction Competence. Lanham, Md.: University Press of America, pp. 63-92.

Jucker, Andreas, and Irma Taavitsainen (2013) English Historical Pragmatics Edinburgh: Edinburgh University Press.

Jucker, Andreas, and Yael Ziv (eds.) (1998) Discourse Markers: Descriptions and Theory. Amsterdam: John Benjamins Publishing Company.

Kytö, Merja, and Jonathan Culpeper (2006) A Corpus of English Dialogues 1560-1760. Uppsala: Uppsala University.

Lakoff, George (1972) Hedges: A study in meaning criteria and the logic of fuzzy concepts. Papers from the $8^{\text {th }}$ Regional Meeting of the Chicago linguistic society. Chicago: University of Chicago Press, pp. 183228.

Lakoff, Robin (1973) The logic of politeness: Or, minding your P's and Q's. Papers from the $9^{\text {th }}$ Regional Meeting of the Chicago Linguistic Society. Chicago: University of Chicago Press, pp. 292-305.

Lauwereyns, Shizuka (2002) Hedges in Japanese conversation: The influence of age, sex and formality. Language Variation and Change 14: 239-259.

Lehman, Christian (1993) Theoretical implications of grammaticalization phenomena. In William Foley (ed.), The Role of Theory in Language Description. Berlin: Mouton de Gruyter, pp. 315-340.

Lerner, Gene (1994) Responsive list construction. Language and Social Psychology 13: 20-33.

Levey, Stephen (2007) The next generation: Aspects of grammatical variation in the speech of some London preadolescents. Ph.D. Dissertation, Queen Mary University of London.

Levey, Stephen (2012) General extenders and grammaticalization: Insights from London preadolescents. Applied Linguistics 33: 257-281.

Macaulay, Ronald (1985) The narrative skills of a Scottish coal miner. In Manfred Görlach (ed.), Focus on: Scotland. Amsterdam: John Benjamins Publishing Company, pp. 101-124.

Meillet, Antoine (1912 [1958]) L'évolution des formes grammaticales. In Linguistique Historique et Linguistique Générale. Paris: Champion, pp. 130-148. Original publication in Scientia (Rivista di Scienza) 12, 1912.

Nevalainen, Terttu, and Matti Risanen (2002) Fairly pretty or pretty fair? On the development and grammaticalization of English downtoners. Language Sciences 24: 359-380.

Norrby, Catrin, and Joanne Winter (2002) Affiliation in adolescents' use of discourse extenders. In Cynthia Allen (ed.), Proceedings of the 2001 Conference of the Australian Linguistic Society. http://www.als.asn.au

Nuyts, Jan (2001) Epistemic Modality, Language, and Conceptualization. Amsterdam: John Benjamins Publishing Company.

Nuyts, Jan (2012) Notions of (inter)subjectivity. English Text Construction 5: 53-76.

O'Keeffe, Anne (2004) "Like the wise virgins and all that jazz": Using a corpus to examine vague categorisation and shared knowledge Language and Computers 52: 1-26. 
Östman, Jan-Ola (1981) You Know: A Discourse-Functional Approach Amsterdam: John Benjamins Publishing Company.

Overstreet, Maryann (1999) Whales, Candlelight and Stuff Like That: General Extenders in English Discourse. New York: Oxford University Press.

Overstreet, Maryann (2005) And stuff, und so: Investigating pragmatic expressions in English and German. Journal of Pragmatics 37: 1845-1864.

Overstreet, Maryann (2011) Vagueness and hedging. In Gisle Andersen, and Karin Aijmer (eds.), Pragmatics of Society. Berlin: Mouton de Gruyter, pp. 293-318.

Overstreet, Maryann, and George Yule (1997a) Locally contingent categorization in discourse. Discourse Processes 23: 83-97.

Overstreet, Maryann, George Yule (1997b) On being inexplicit and stuff in contemporary American English. Journal of English Linguistics 25: 250-258.

Overstreet, Maryann, and George Yule (2001) Formulaic disclaimers. Journal of Pragmatics 33: 45-60.

Overstreet, Maryann, and George Yule (2002) The metapragmatics of and everything. Journal of pragmatics 34: 785-794.

Palacios Martínez, Ignacio (2011) 'I might, I might go I mean it depends on money things and stuff: A preliminary analysis of general extenders in British teenagers' discourse. Journal of Pragmatics 43: 24522470 .

Parvaresh, Vahid, Manoochehr Tavangar, Abbas Eslami Rasekh, and Dariush Izadi (2012) About his friend, how good she is, and this and that: General extenders in native Persian and non-native English discourse. Journal of Pragmatics 44: 261-279.

Pichler, Heike, and Stephen Levey (2010) Variability in the co-occurrence of discourse features. Language Studies Working Papers 2: 17-27.

Pichler, Heike, and Stephen Levey (2011) In search of grammaticalization in synchronic dialect data: General extenders in northeast England. English Language and Linguistics 15: 441-471.

Prévost, Sophie (2011) A propos from verbal complement to discourse marker: A case of grammaticalization? In Liesbeth Degand, and Anne-Marie Simon-Vandenbergen (eds.), (2011) Grammaticalization, pragmaticalization and/or (inter)subjectification: Methodological issues for the study of discourse markers thematic issue. Linguistics 49.2: 391-413.

Roth-Gordon, Jennifer (2007) Youth, slang, and pragmatic expressions: Examples from Brazilian Portuguese. Journal of Sociolinguistics 11: 322-345.

Ruzaite, Jurate (2010) Translation equivalents of vague language items: A study of general extenders in a parallel corpus. Studies about Languages 16: 33-38.

Schiffrin, Deborah (1987) Discourse Markers. Cambridge: Cambridge University Press.

Schourup, Lawrence (1999) Discourse markers. Lingua 107: 227-265.

Secova, Maria (2011) Discourse-pragmatic features of spoken French: Analysis and pedagogical implications. Ph.D. dissertation, Queen Mary University of London.

Simpson, Rita (2004) Stylistic features of academic speech: The role of formulaic expressions. In Ulla Connor, and Thomas Upton (eds.), Discourse in the Professions. Amsterdam: John Benjamins Publishing 


\section{Maryann Overstreet}

Company, pp. 37-64.

Stenström, Anna-Brita, Gisle Andersen, and Ingrid Hasund (2002) Trends in Teenage Talk. Amsterdam: John Benjamins Publishing Company.

Stubbe, Maria, and Janet Holmes (1995) You know, eh and other "exasperating expressions": An analysis of social and stylistic variation in the use of pragmatic devices in a sample of New Zealand English. Language and Communication 15: 63-88.

Tagliamonte, Sali (2011) Variationist Sociolinguistics: Change, Observation, Interpretation. Oxford: Wiley-Blackwell.

Tagliamonte, Sali, and Derek Denis (2010) The stuff of change: General extenders in Toronto, Canada. Journal of English Linguistics 38: 335-368.

Terraschke, Agnes (2007) Use of general extenders by German non-native speakers of English. International Review of Applied Linguistics 45: 141-160.

Terraschke, Agnes, and Janet Holmes (2007) "Und tralala": Vagueness and general extenders in German and New Zealand English. In Joan Cutting (ed.), Vague Language Explored. Basingstoke: Palgrave MacMillan, pp. 198-220.

Traugott, Elizabeth (1982) From propositional to textual and expressive meanings: Some semanticpragmatic aspects of grammaticalization. In Winfred Lehmann, and Yakov Malkiel (eds.), Perspectives on Historical Linguistics. Amsterdam: John Benjamins Publishing Company, pp. 245-271.

Traugott, Elizabeth (2003a) From subjectification to intersubjectification. In Raymond Hickey (ed.), Motives for Language Change. Cambridge: Cambridge University Press, pp. 124-139.

Traugott, Elizabeth (2003b) Constructions in grammaticalization. In Brian Joseph, and Richard Janda (eds.), The Handbook of Historical Linguistics Oxford: Blackwell, pp. 624-647.

Traugott, Elizabeth (2007) (Inter)subjectification and unidirectionality. Journal of Historical Pragmatics 8: 295-309.

Traugott, Elizabeth (2010) Revisiting subjectification and intersubjectification. In Kristin Davidse, Lieven Vandelanotte, and Hubert Cuyckens (eds.), Subjectification, Intersubjectification and Grammaticalization. Berlin: Mouton de Gruyter, pp. 29-70.

Traugott, Elizabeth, and Richard Dasher (2002) Regularity in Semantic Change. Cambridge: Cambridge University Press.

Traugott, Elizabeth, and Bernd Heine (eds.) (1991) Approaches to grammaticalization. Volumes I and II. Amsterdam: John Benjamins Publishing Company.

Vincent, Diane, and David Sankoff (1992) Punctors: A pragmatic variable. Language Variation and Change 4: 205-216.

Ward, Gregory, and Betty Birner (1993) The semantics and pragmatics of and everything. Journal of Pragmatics 19: 205-214.

Warren, Martin (2007) \{/ [Oh ] Not a <^ Lot > \}: Discourse intonation and vague language. In Joan Cutting (ed.), Vague Language Explored. Basingstoke: Palgrave Macmillan, pp. 182-197.

Watts, Richard (1989) Taking the pitcher to the 'well': Native speakers' perception of their use of discourse markers in conversation. Journal of Pragmatics 13: 203-237.

Winter, Joanne, and Catrin Norrby (2000) "Set marking tags" and stuff. In John Henderson (ed.), 
Proceedings of the 1999 Conference of the Australian Linguistic Society.

http://www.linguistics.uwa.edu.au/research/als99/proceedings

Youssef, Valerie (1993) Marking solidarity across the Trinidad speech community: The use of an ting in medical counselling to break down power differentials. Discourse and Society 4: 291-306.

MARYANN OVERSTREET is an Associate Professor in the Department of Languages and Literatures of Europe and the Americas at the University of Hawai'i. Her research areas are sociopragmatics, discourse analysis, the cross-linguistic study of pragmatic expressions, and socio-psycholinguistic perspectives on linguistic categorization. Her publications include Whales, Candlelight, and Stuff Like That: General Extenders in English Discourse (Oxford University Press, 1999) and articles in Discourse Processes, Journal of English Linguistics and Journal of Pragmatics.

Address:University of Hawai'i at Manoa, 1890 East West Road, Moore \#483, Honolulu, HI 96822, United States. E-mail: overst@hawaii.edu 